\title{
PERANCANGAN APLIKASI "REKAM MEDIS" MENGGUNAKAN METODE PROTOTYPING PADA UPT.PUSKESMAS KALITANJUNG CIREBON
}

\author{
Jessica Felicia Callista, Lena Magdalena, Rifqi Fahrudin \\ Program Studi Sistem Informasi \\ Universitas Catur Insan Cendekia \\ Jl. Kesambi 202 Kota Cirebon, Jawa Barat, Indonesia \\ jessicafelicia.99@gmail.com, lena.magdalena@cic.ac.id,rifqifhrdn@gmail.com
}

\begin{abstract}
Abstrak
Di jaman era serba Teknologi dan Internet ini sangat menguntungkan dikarenakan semakin mempermudah manusia dalam pekerjaannya tak terkecuali pada bidang kesehatan. Rekam Medis Pasien yang dapat memberikan kemudahan dan juga sangat mendukung dalam melakukan kegiatan pengolahan/pencatatan rekam medis yang akan di mulai dari pasien datang melakukan registrasi pasien sampai dengan pasien mendapati obat. Semua prosedur pencatatan rekam medis akan tercatat kedalam sistem informasi Rekam Medis ini terkomputerisasi berbasis media komputer yang mempermudah saluran data \& informasi terkait kegiatan medis dan pelayanan pasien. Metode penelitian yang digunakan adalah salah satu pengembangan sistem perangkat lunak yaitu metode protoype, bertujuan untuk percobaan rancangan, dan dalam pengumpulan kebutuhan akan melibatkan pengembang dan pengguna sistem untuk menentukan tujuan, fungsi dan kebutuhan operasional sistem. Hasil akhir dari penelitian ini ialah Perancangan Aplikasi Sistem Informasi Rekam Medis berbasis web menjadikan tindakan- tindakan pelayanan medis lainnya agar dapat terintegrasi dengan baik terhadap data lainnya yang ada.
\end{abstract}

Kata kunci: Perancangan, Rekam medis, Puskesmas.

\begin{abstract}
In this era of all-technology and the Internet, it is very beneficial because it makes it easier for humans to work, including in the health sector. Patient Medical Records that can provide convenience and are also very supportive in carrying out processing/recording of medical records which will start from the patient coming to register the patient until the patient finds
\end{abstract}

the drug. All medical record recording procedures will be recorded into the Medical Record information system, computerized based on computer media which makes it easier to channel data \& information related to medical activities and patient services. The research method used is one of the software systems development, namely the prototype method, aims to design experiments, and in gathering requirements will involve system developers and users to determine the objectives, functions and operational needs of the system. The final result of this research is the design of a web-based Medical Record Information System to make other medical service actions so that they can be well integrated with other existing data.

Keywords: Design, Medical records, Public health center.

\section{Pendahuluan}

Seiring dengan berjalannya waktu perkembangan terjadi di era digital seperti teknologi dan internet yang sangat menguntungkan karena semakin mempermudah manusia dalam pekerjaannya tak terkecuali pada bidang kesehatan khususnya yang terjadi pada perkembangan sistem informasi berbasis web telah mengalami perubahan sangat pesat yaitu dengan adanya sistem informasi rekam medis pada lembaga pelayanan kesehatan masyarakat khususnya pada Puskesmas yang akan sangat mendukung dalam melakukan kegiatan pengolahan/pencatatan rekam medis yang akan di mulai dari pasien datang melakukan registrasi identitas pasien, mengambil nomor antrian, mencetak kartu pasien, kartu pasien berobat, pasien juga dapat melihat informasi jadwal dokter pada portal, mendapati pemeriksaan dari petugas medis hingga pemberian resep obat,pengambilan obat ke apoteker serta layanan dan tindakan lainnya yang akan diberikan kepada pasien 
hingga pasien keluar dari lembaga pelayanan kesehatan Puskesmas.

Dari setiap layanan/tindakan medis pihak Lembaga kesehatan atau puskesmas berikan pada pasien harus dinyatakan terintegrasi karena yang terjadi puskesmas ini mempunyai kendala atau permasalahan pada pengolahan data yang belum terkomputerisasi khususnya pada unit rekam medis pasien. Di mana pengolahan datanya masih secara manual dan tidak berintegrasi dengan data lainnya. Pada petugas medis UPT.Puskesmas Kalitanjung Cirebon mengalami kesulitan yang mengharuskan memakan waktu banyak dikarenakan dari semua dokumen ataupun berkas yang tersaji masih berupa lembaran-lembaran kertas (fisik) yang disimpan di dalam rak/lemari arsip yang dimana dinyatakan tidak terintegrasi bahkan mengalami pencatatan duplikat pada nomor rekam medis pasien dikarenakan kegiatan pembuatan laporan yang berjalan masih dilakukan secara manual yang mengakibatkan kondisi yang sangat tidak efektif,efisien dan tidak aman.

Untuk itu, perlu adanya sebuah website rekam medis pasien yang dapat memberikan kemudahan bagi petugas puskesmas dalam pengolahan data petugas seperti data admin, pasien, poliklinik, dokter, apoteker, obat, dan sebagainya. Oleh karena itu, untuk mengatasi permasalahan dari latarbelakang tersebut maka penulis akan merancang sebuah aplikasi sistem informasi rekam medis dengan menggunakan salah satu metode pengembangan sistem perangkat lunak yaitu metode protoype, yang merumuskan ide ataupun rencana, percobaan rancangan, dan menemukan lebih banyak masalah dan solusi yang memungkinkan, dalam pengumpulan kebutuhan akan melibatkan pengembang dan pengguna sistem untuk menentukan tujuan, fungsi dan kebutuhan operasional sistem. Adapun alasan-alasan pemakai maupun spesialis informasi menyukai model prototype adalah: 1) Komunikasi antara analis sistem dan pemakai membaik; 2) Analis dapat bekerja dengan lebih baik dalam menemukan kebutuhan pemakai; 3)Pemakai berperan lebih aktif dalam pengembangan sistem; 4)Spesialis informasi dan pemakai menghabiskan lebih sedikit waktu dan usaha dalam mengembangkan sistem; 5)Implementasi menjadi lebih mudah karena pemakai mengetahui sistem yang diharapkan [1].

Berdasarkan latar belakang yang telah diuraikan diatas, maka penulis akan membuat Sistem Informasi Rekam Medis Pasien demi meningkatkan mutu pelayanan kesehatan pada Puskesmas Kalitanjung dengan judul "PERANCANGAN APLIKASI REKAM MEDIS MENGGUNAKAN METODE PROTOTYPING PADA UPT.PUSKESMAS KALITANJUNG KOTA CIREBON"

\section{TinjauAn Pustaka}

\section{II.1 Tinjauan Pustaka}

Adapun Tinjauan Pustaka dalam menyusun penelitian ini penulis mengkaitkan dengan beberapa karya ilmiah terdahulu, sehingga akan didapatkan keterkaitan dengan beberapa karya ilmiah tersebut. Adapun karya ilmiah yang penulis maksud adalah sebagai berikut:

Penelitian yang dilakukan sebelumnya Jurnal oleh Taufik Rahman, Lukman Hakim dan Okta Maya Sari (2020) dengan judul "Sistem Informasi Rekam Medis Pada Dinas Kesehatan Kabupaten Musirawas Berbasis Web Mobile" Dalam penelitian ini , peneliti merancang sistem rekam medis pasien yang bisa langsung selaras dan tersinkron untuk ke beberapa Puskesmas yang ada di Kabupaten Musirawas, metode penelitian yang digunakan dalam penelitian ini adalah metode pengembangan sistem dengan metode Waterfall, metode ini menyiratkan pendekatan yang sistematis dan berurutan pada perangkat lunak yang dimulai dari perencanaan (planning), pemodelan (modeling), konstruksi (construction), serta penyerahan perangkat lunak kepada pelanggan (deployment). [2]

Jurnal Skripsi oleh Ita Dewi Sintawati, Widiarina (2020) Jurusan Program Studi Sistem Informasi Fakultas Teknik dan Informatika Universitas Bina Sarana Informatika Jakarta dengan judul "Penerapan Metode Prototype Untuk Sistem Informasi Pengadaan Barang Berbasis Web" penelitian ini membahas kegiatan pengadaan barang atau jasa. Untuk memperoleh barang melalui perencanaan kebutuhan sampai dengan terselesaikannya seluruh kegiatan untuk mendapatkan barang yang dibutuhkan. Namun pada objek penelitian perusahaan masih melakukan kegiatan pengadaan barang ini secara manual. Metode yang diterapkan menggunakan metode pengembangan sistem informasi prototype yang mampu digunakan kedalam sistem kecil maupun besar dengan harapan agar proses pembangunan sistem dapat berjalan dengan baik, tertata serta selesai tepat waktu/hemat waktu selain itu Cocok digunakan pada sebuah sistem lingkup internal, yang digunakan pada ruang lingkup

Jessica Felicia Callista, Lena Magdalena, Rifqi Fahrudin 
tertentu, seperti sistem di dalam sebuah kantor. [3]

Dapat disimpulkan dari tinjauan pustaka diatas ditemukan persamaan dan perbedaan dengan penelitian yang sedang peneliti teliti. Adapun persamaannya yaitu membahas terkait sistem informasi manajemen puskesmas (Rekam Medis) yakni memiliki kendala dimana belum tersedianya media penyimpanan data pasien dan rekam medis pasien. Mengenai perbedaannya yaitu terletak di aspek manajemen yang dibahas, yaitu penelitian yang peneliti rancang lebih terfokus kepada tentang aspek pelayanan instansi kesehatan seperti Sistem pendaftaran pasien secara online melalui website tanpa harus datang ke puskemas, dan melakukan cetak kartu pasien pada puskesmas, Adanya nomor antrian dapat di akses melalui website, dan melakukan cetak antrian pada puskesmas hingga adanya portal web yang dapat di akses pasien/pengunjung untuk melihat jadwal dokter.

\section{II.2 Metode Penelitian}

Pada penelitian ini peneliti menggunakan Metode Prototype sebagai salah satu metode pengembangan perangkat lunak merupakan metode siklus hidup sistem yang didasarkan pada konsep model bekerja (working model). Dengan menggunakan Metode prototyping , pengembang sistem dan pengguna dapat saling berinteraksi selama proses pembuatan sistem . Sering terjadi seorang pengguna hanya mendefinisikan secara umum apa yang dibutuhkan, pemrosesan dan data-data apa saja yang dibutuhkan. Sebaliknya, disisi pengembang kurang memperhatikan efisiensi Algoritma . Kemampuan sistem operasi dan interface yang menghubungkan manusia dengan komputer. [4]

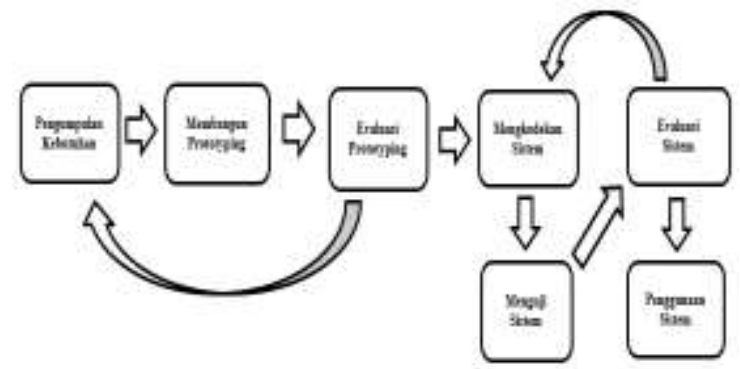

Gambar 1. Tahapan Metode Prototype

Adapun tahapan metode prototype/prototyping:

a) Pengumpulan Kebutuhan
b) Membangun Prototype / Prototyping
c) Evaluasi Prototyping
d) Mengkodekan Sistem
e) Menguji Sistem
f)Evaluasi Sistem
g) Menggunakan Sistem

\section{II.3 Skema Alur Penelitian}

Diagram alur penelitian merupakan gambaran umum terkait alur penelitian yang akan dilakukan dalam pengerjaan penelitian skripsi ini dari awal hingga akhir. Alur kerja dari pengerjaan penelitian ini dapat dilihat pada gambar 2 berikut :

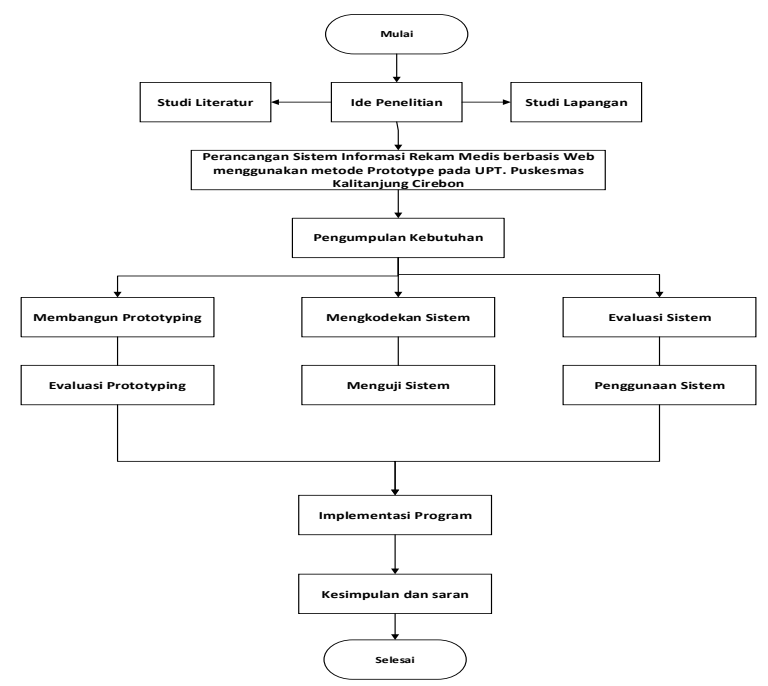

Gambar 2. Diagram Alur Penelitian

Penjelasan Diagram Alur Penelitian, langkah penelitian ditunjukkan dalam bentuk diagram alir langkah penelitian sebagai berikut :

a). Mulai, Pada proses ini penulis memulai untuk mengerjakan penelitian mengenai Sistem Informasi Rekam Medis berbasis web pada UPT. Puskesmas Kalitanjung Cirebon.

b). Ide Penelitian, Adanya Ide penelitian didapatkan dari penelitian yang telah dilakukan sebelumnya diikuti fakta-fakta dan atas saran dosen pembimbing.

c). Judul Penelitian, Dari permasalahan ini, maka ditemukan suatu ide penelitian yaitu "Perancangan Sistem Informasi Rekam Medis Berbasis web dalam peningkatan mutu pelayanan kesehatan menggunakan metode Prototype pada UPT.Puskesmas Kalitanjung kota Cirebon"

Jessica Felicia Callista, Lena Magdalena, Rifqi Fahrudin 
d). Pengumpulan Kebutuhan, Dalam tahap ini penulis melakukan pengumpulan data dan informasi untuk mengetahui terkait system yang berjalan pada objek penelitian.

e). Membangun Prototyping, Merupakan tampilan perancangan bentuk interface (tampilan visual) program yang dibuat, dengan tujuan supaya pemakai mudah di mengerti dari system yang akan dibuat disesuaikan dengan kebutuhan sistem yang telah didefinisikan sebelumnya dari keluhan pengguna system.

f). Evaluasi Prototyping, Melakukan evaluasi pada rancangan tampilan ataupun rancangan UML yang telah dibuat pada tahap membangun prototyping.

g). Mengkodekan Sistem, Ketika prototyping Sistem Informasi Rekam Medis Puskesmas Kalitanjung yang sudah di konfirmasi keputusannya lalu diwujudkan ke dalam bahasa pemrograman menggunakan Bahasa pemrograman PHP.

h). Menguji Sistem, Dari tahap mengkodekan system menggunakan Bahasa pemrograman yang telah menjadi suatu software yang siap pakai, maka software harus dilakukan uji coba sebelum digunakan.

i). Evaluasi Sistem, Tahap ini melakukan evaluasi suatu Perangkat lunak (software) dievaluasi oleh user untuk menentukan apakah sistem sudah memenuhi kebutuhan user atau belum, Jika masih ada kekurangan maka harus melakukan perbaikan sistem

j). Penggunaan Sistem, Pada tahap terakhir yaitu dimana Perangkat lunak (software) yang sudah diuji dan disetujui oleh pengguna dapat siap digunakan.

k). Implementasi Program, Tahap pembuatan dan implementasi program yang sudah siap pakai, yaitu memiliki kriteria adalah program mudah dalam digunakan dan program mudah dipahami oleh pengguna.

1). Kesimpulan dan Saran, Berisikan hasil akhir yang diperoleh setelah penelitian selesai dan saran pembangun yang berkenaan dengan hasil yang telah dicapai.

\section{II.4 Pengumpulan Data \& Analisis Data}

Pengumpulan Data

Pengumpulan data menjelaskan metode pengumpulan data dan data yang dibutuhkan baik data primer yaitu data yang diperoleh secara langsung dari sebuah subjek atau pun objek penelitian, wawancara dan studi pustaka. [5]
Analisis Data

Terdapat kebutuhan data dalam membangun sistem informasi rekam medis yang digunakan penulis sebagai bahan penelitian diambil dari proses input yang membentuk sistem informasi berupa jenis sumber daya yang ada pada sistem informasi saat ini sebagai berikut:

a. Dalam pembangunan sistem informasi, sumber data yang dibutuhkan dalam Sistem Informasi Rekam Medis bersumber dari bagian rekam medis UPT Puskesmas Kalitanjung kota Cirebon.

b. Sumber data mencakup dari pengguna sistem yang terlibat langsung dalam pengelolaan data dan Sistem Informasi Rekam Medis yaitu Kepala Puskesmas, bagian staff medis (admin, dokter, apoteker \& kepala puskesmas).

c. Sumber data yang dibutuhkan dalam sistem informasi rekam medis adalah data identitas pasien, data hasil pemeriksaan pasien, data pelayanan yang diberikan.

\section{ANALisis dan Perancangan}

Studi Kasus : Penelitian dengan judul " Sistem Informasi Rekam Medis pasien berbasis Web Dalam Peningkatan Mutu Pelayanan Kesehatan Menggunakan Metode Pengembangan pada UPT. Puskesmas Kalitanjung Kota Cirebon. ini:

Berikut Hasil dan Pembahasan pada penelitian

\section{III.1 Pengumpulan Kebutuhan}

Berfokus terhadap fitur - fitur yang dikembangkan dalam sistem. Dalam sistem terdapat 5 hak akses pengguna yaitu pasien, dokter, admin, apoteker dan Kepala Puskesmas . Berikut adalah fitur yang ada di sistem :

Untuk fitur level pasien dengan rincian sebagai berikut :

a. Halaman untuk Home portal web UPT.Puskesmas Kalitanjung.

b. Halaman Tentang Kami

c. Halaman Hubungi Kami

d. Halaman Jadwal Praktek Dokter pada portal web.

e. Halaman Cara Berobat

Jessica Felicia Callista, Lena Magdalena, Rifqi Fahrudin 
f. Halaman Daftar Berobat

g. Halaman Login pasien.

h. Profil Pasien.

i. Halaman Cetak Kartu Pasien berobat.

j.Halaman untuk melihat histori pendaftaran

k. Halaman untuk Cetak Antrian.

1. Logout

Sedangkan untuk fitur bagian dokter adalah sebagai berikut :

a. Halaman Login user dokter.

b. Halaman Menu Data Master, terdapat sub menu data dokter $\&$ data pasien.

c. Halaman Menu Pemeriksaan. Terdapat sub menu antrian pasien, pasien sudah diperiksa dan pasien dirujuk.

d. Halaman Menu Laporan. Terdapat sub menu laporan rekam medis.

e. Logout.

Sedangkan untuk fitur bagian administrasi adalah sebagai berikut :

a. Halaman Login user admin.

b. Halaman Menu Data Master, terdapat sub menu data poli, data admin, data pasien, data dokter, data apoteker dan data kepala puskesmas.

c. Halaman Pendaftaran. Terdapat sub menu pendaftaran pasien terbagi menjadi beberapa poli dan data pendaftaran pasien perhari.

d. Halaman Laporan. Terdapat sub menu laporan , laporan daftar dokter, laporan daftar apoteker, laporan daftar pasien dan laporan daftar pasien yang sudah berobat.

\section{e. Logout}

Sedangkan untuk fitur bagian apoteker adalah sebagai berikut :

a. Halaman login user apoteker.

b. Halaman Menu Data Master, terdapat sub menu data apoteker, data pasien, data satuan, dan data obat. c. Halaman Menu Persediaan Obat, terdapat tabel persediaan obat.

d. Halaman Menu Transaksi, terdapat sub menu Penyerahan Obat, terdapat tabel antrian pasien yang sudah diberi resep obat oleh dokter, dan sub menu Data Penyerahan Obat, yaitu tabel data Pasien yang sudah menerima obat.

e. Halaman Menu Laporan, terdapat sub menu Laporan Persediaan Obat yang dapat dicetak, dan sub menu Laporan Penyerahan Obat yang dapat dicetak.

\section{f. Logout.}

Sedangkan untuk fitur bagian Kepala Puskesmas adalah sebagai berikut :

a. Halaman Login user Kepala Puskesmas.

b. Halaman Menu Laporan, Terdapat laporan rekam medis.

c. Dapat melihat data laporan rekam medis

d. Dapat mencari data laporan rekam medis

e. Data mencetak data laporan rekam medis

f. Logout

\section{III.2 Membangun Prototype}

Membangun prototyping dengan membuat perancangan sementara yang berpusat pada penyajian kepada pelanggan misalnya dengan membuat input dan contoh outputnya. Perancangan dapat dilihat pada use case diagram administrator, dokter, pasien, apoteker dan kepala puskesmas.

Jessica Felicia Callista, Lena Magdalena, Rifqi Fahrudin 


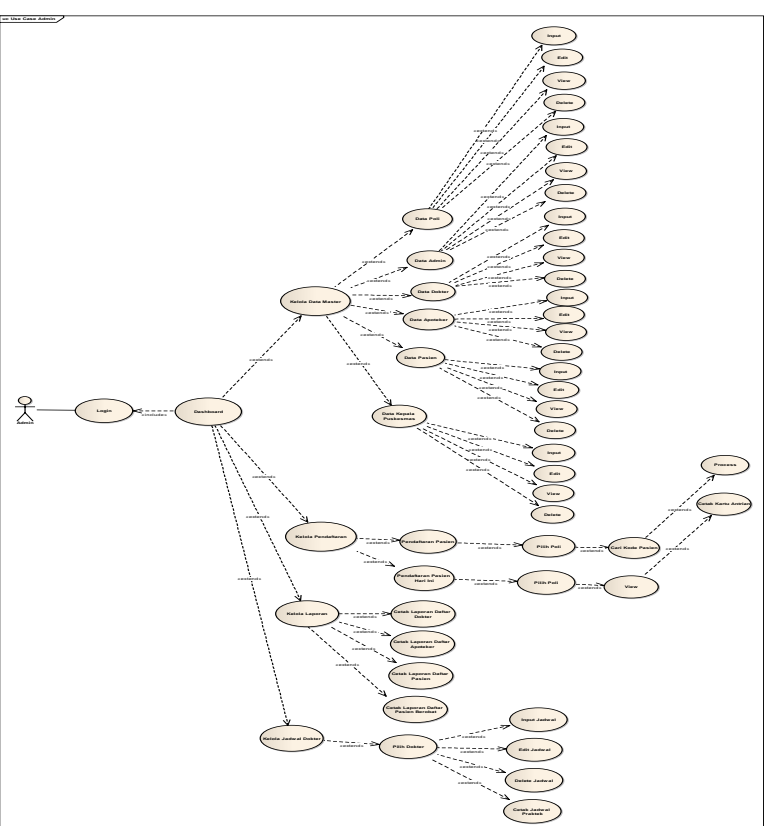

Gambar 3. Usecase Diagram Admin

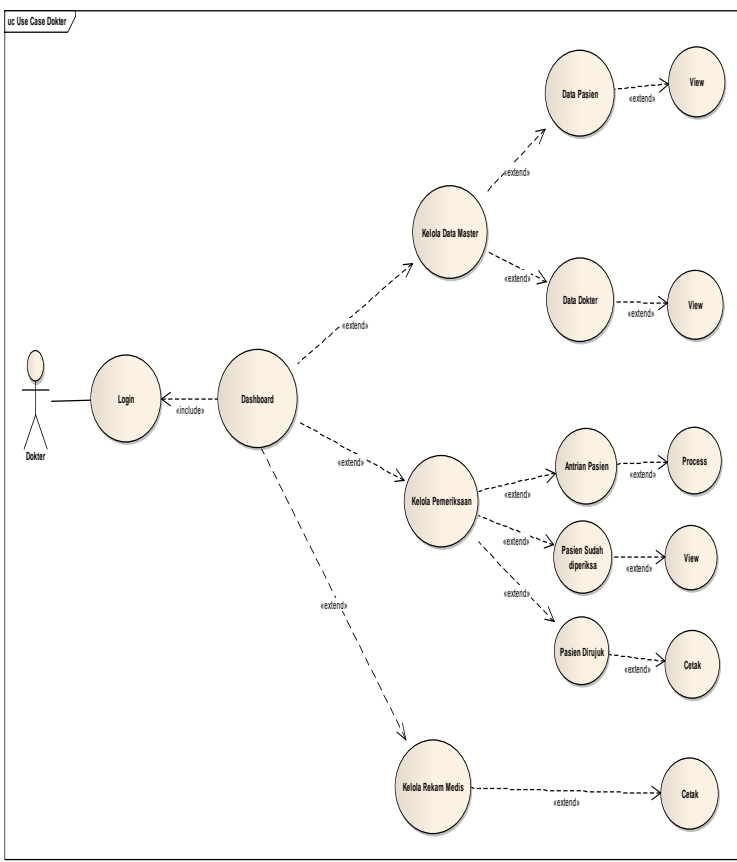

Gambar 4. Usecase Diagram Dokter

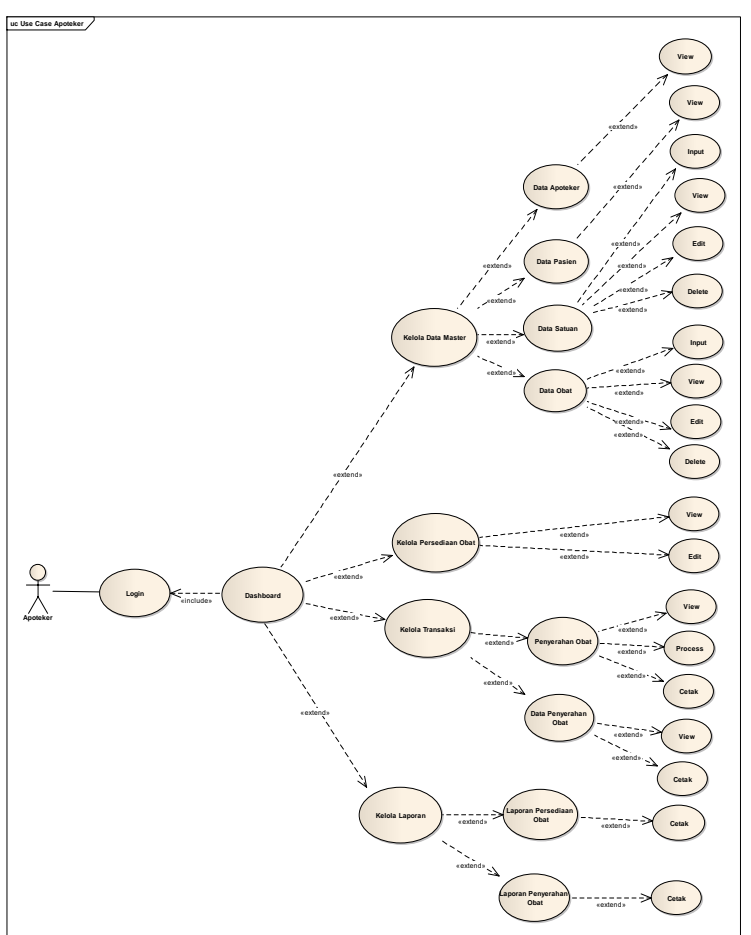

Gambar 5. Usecase Diagram Apoteker 


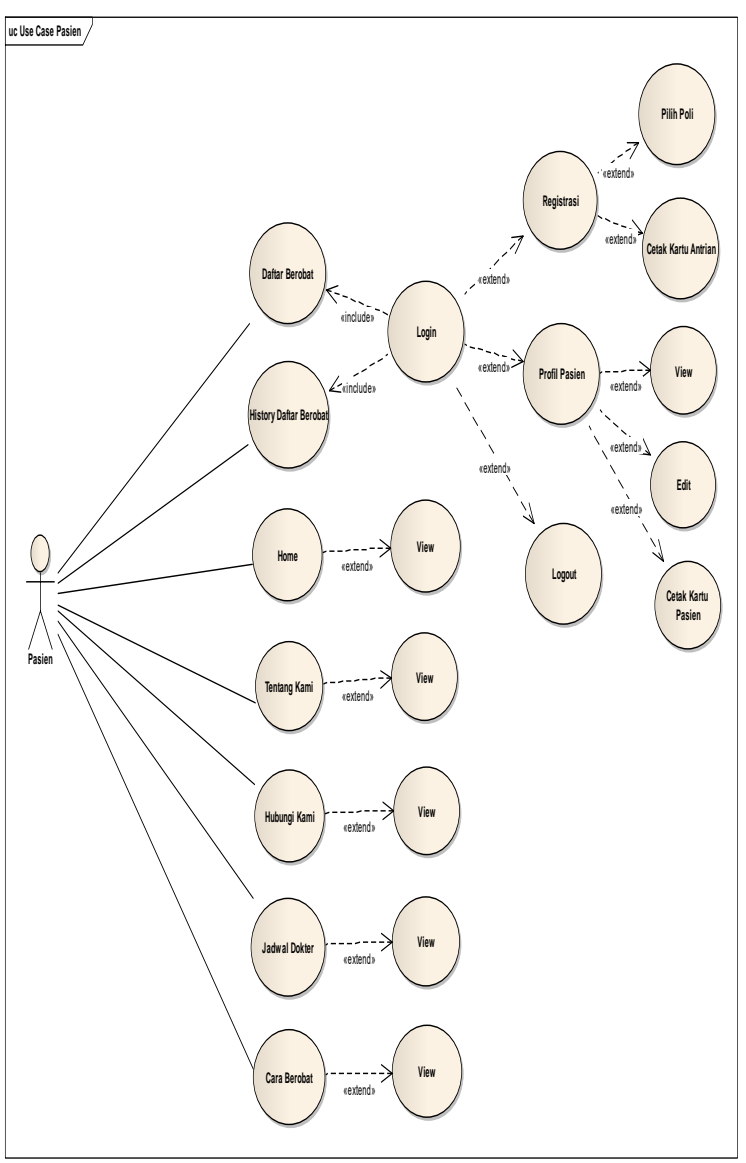

Gambar 6. Usecase Diagram Pasien

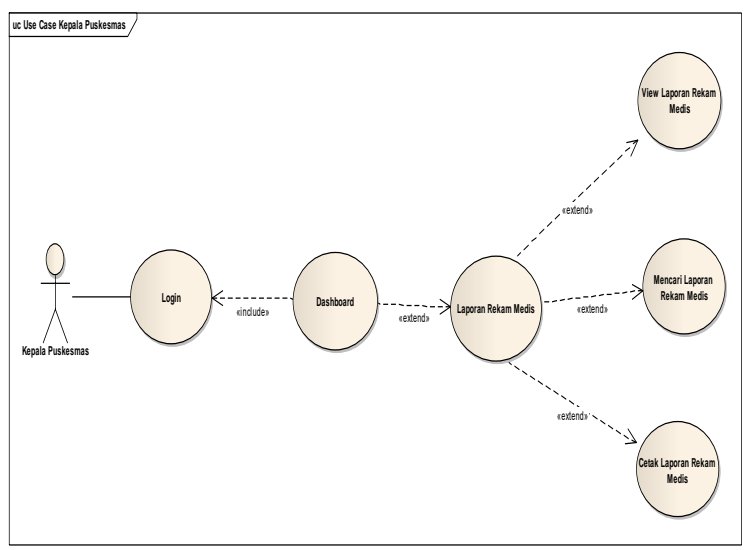

Gambar 7. Usecase Diagram Kepala Puskesmas

\section{III.3 Evaluasi Prototype}

Evaluasi ini dilakukan oleh pelanggan apakah prototyping yang sudah dibangun sudah sesuai dengan keinginan pelanggan. jika sudah sesuai maka langkah keempat akan diambil. Jika tidak, maka prototyping diperbaiki dengan mengulang langkah 1 , 2 , dan 3. Hasil evaluasi dari prototype yang dibuat adalah prototype dilanjutkan ke tahap pengkodean.

\section{III.4 Pengkodean Sistem}

Pada tahap ini prototipe dibuat dengan bahasa pemrograman PHP dengan konsep php Native. Hasil dari pengodean dapat dilihat pada gambar di bawah ini.

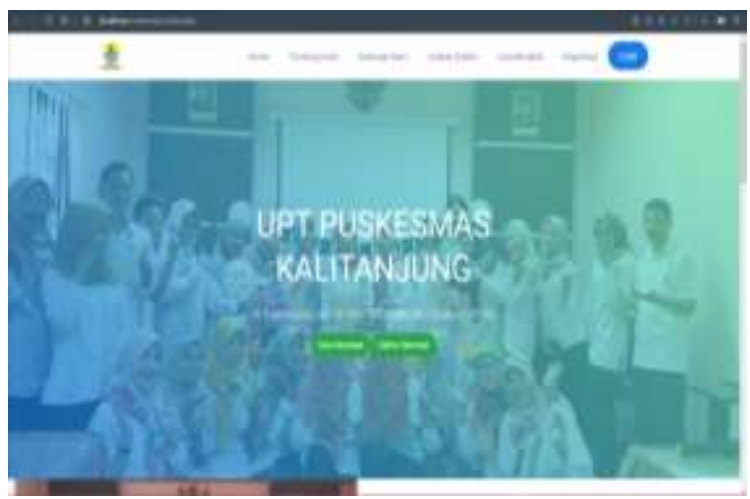

Gambar 8. Dashboard Utama Web Pasien

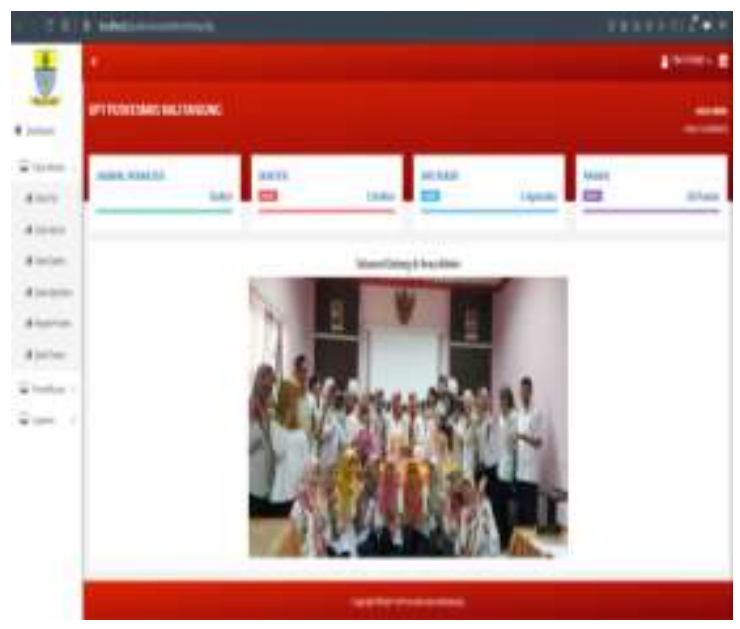

Gambar 9. Dashboard Utama Web Admin 


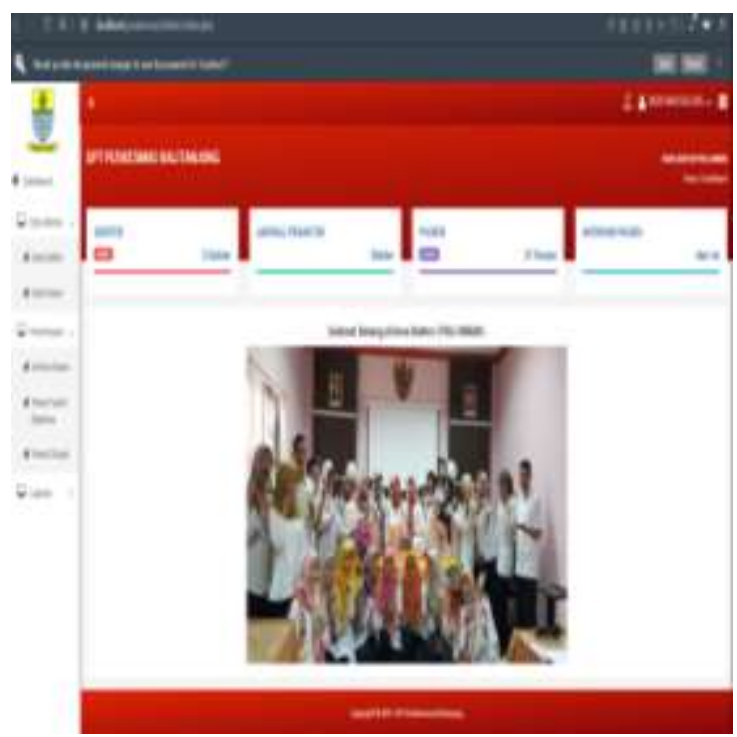

Gambar 10. Dashboard Utama Web Dokter

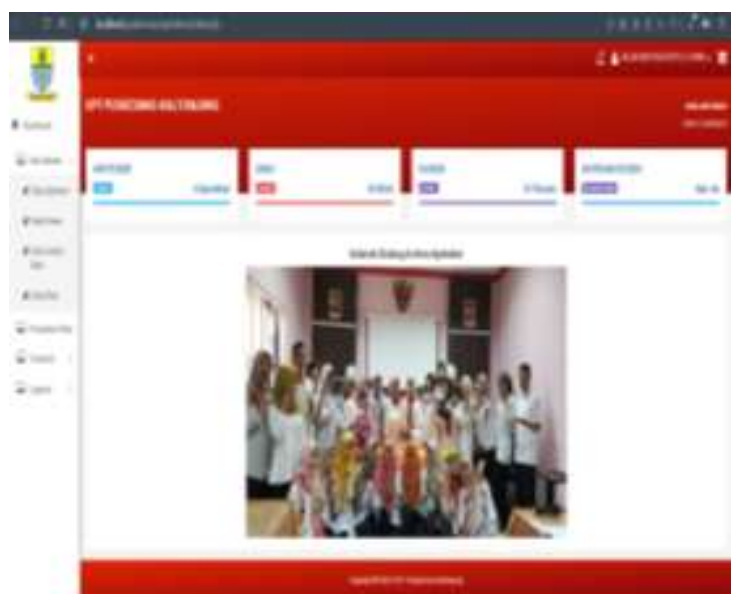

Gambar 11. Dashboard Utama Web Apoteker

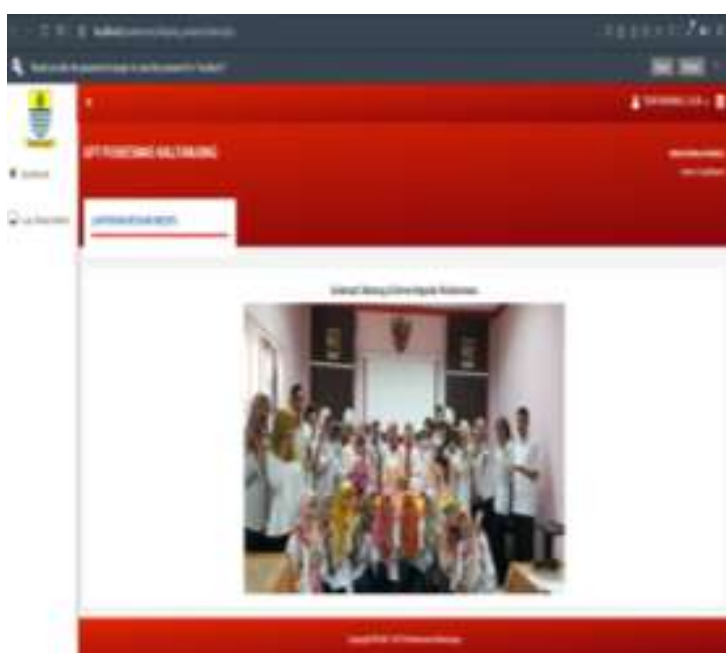

Gambar 12. Dashboard Utama Web Kepala Puskes

\section{III.5 Pengujian Sistem}

Setelah sistem sudah menjadi suatu perangkat lunak yang siap pakai, harus dites dahulu sebelum digunakan. Pengujian ini dilakukan dengan metode blackbox testing. [5]

Tabel 1. Hasil Pengujian Form Login

\begin{tabular}{|c|c|c|c|c|c|}
\hline No. & Jenis Uji & Data Uji & $\begin{array}{l}\text { Hasil yang } \\
\text { Dilarapkan }\end{array}$ & $\begin{array}{c}\text { Hasil } \\
\text { Keluaran }\end{array}$ & $\begin{array}{l}\text { Hasil } \\
\text { Uji }\end{array}$ \\
\hline 1 & Login & $\begin{array}{l}\text { Username } \\
\text { kosong }\end{array}$ & $\begin{array}{l}\text { Muncul message } \\
\text { harap isi username }\end{array}$ & $\begin{array}{l}\text { Muncul } \\
\text { message }\end{array}$ & Valid \\
\hline 2 & $\log i n$ & $\begin{array}{l}\text { Password } \\
\text { kosong }\end{array}$ & $\begin{array}{l}\text { Muncul message } \\
\text { harap isi password }\end{array}$ & $\begin{array}{l}\text { Muncul } \\
\text { messagge }\end{array}$ & Valid \\
\hline 3 & $\log i n$ & $\begin{array}{l}\text { Usernome } \\
\text { dan } \\
\text { Password } \\
\text { kosong }\end{array}$ & $\begin{array}{l}\text { Muncul message } \\
\text { "Username tidak } \\
\text { boleh kosong" } \\
\text { "Password tidak } \\
\text { bolch kosong" }\end{array}$ & $\begin{array}{l}\text { Muncul } \\
\text { message }\end{array}$ & Valid \\
\hline 4 & $\log$ in & $\begin{array}{l}\text { Username } \\
\text { dan } \\
\text { Password } \\
\text { lerisi data } \\
\text { tidak valid }\end{array}$ & $\begin{array}{l}\text { Muneul message } \\
\text { "Login Gagal, } \\
\text { Username atau } \\
\text { Password Salah" }\end{array}$ & $\begin{array}{l}\text { Muncul } \\
\text { message }\end{array}$ & Valid \\
\hline 5 & Login & $\begin{array}{l}\text { Userriame } \\
\quad \text { dan } \\
\text { Password } \\
\text { terisi data } \\
\text { valid }\end{array}$ & $\begin{array}{l}\text { Muncul halaman } \\
\text { dashboard }\end{array}$ & $\begin{array}{c}\text { Tampil } \\
\text { halaman }\end{array}$ & Valid \\
\hline
\end{tabular}


Tabel 2. Hasil Pengujian Menu dan Submenu Dokter

\begin{tabular}{|c|c|c|c|c|c|}
\hline Na. & Jeais Lji & Data $\mathrm{L}_{j \mathrm{i}}$ & $\begin{array}{l}\text { Hasal yang } \\
\text { Diharapkan }\end{array}$ & $\begin{array}{c}\text { Hasil } \\
\text { Keluaran }\end{array}$ & $\frac{\mathrm{Hasil}}{\mathrm{Uji}^{-1 i}}$ \\
\hline 1 & $\begin{array}{c}\text { Menu } \\
\text { Dashboand }\end{array}$ & $\begin{array}{l}\text { Klit Menu } \\
\text { Dashboard }\end{array}$ & $\begin{array}{l}\text { Tampil halaman } \\
\text { dasbboand }\end{array}$ & $\begin{array}{c}\text { Tampil } \\
\text { halaman }\end{array}$ & Valid \\
\hline 2 & $\begin{array}{l}\text { Menu Data } \\
\text { Master }\end{array}$ & $\begin{array}{l}\text { Klit Menua } \\
\text { Data Master }\end{array}$ & $\begin{array}{c}\text { Muncul sabmena } \\
\text { Data Dokter dan } \\
\text { Data Pasien }\end{array}$ & $\begin{array}{c}\text { Tampil } \\
\text { Subment }\end{array}$ & Valid \\
\hline 3 & $\begin{array}{c}\text { Menu } \\
\text { Pemeriksaam }\end{array}$ & $\begin{array}{l}\text { Kiti Mesm } \\
\text { Pemeriksaan }\end{array}$ & $\begin{array}{l}\text { Muncul submenu } \\
\text { Antrian Pasien, } \\
\text { Pasien sudah } \\
\text { diperiksa dan } \\
\text { Pasien dirujuk }\end{array}$ & $\begin{array}{c}\text { Tampil } \\
\text { Submenu }\end{array}$ & Valid \\
\hline 4 & $\begin{array}{c}\text { Memu } \\
\text { Laporan }\end{array}$ & $\begin{array}{l}\text { Kitik Benw } \\
\text { Laporan }\end{array}$ & $\begin{array}{l}\text { Mancul submenu } \\
\text { Laporan Rekam } \\
\text { Medis }\end{array}$ & $\begin{array}{l}\text { Tampil } \\
\text { halaman }\end{array}$ & Valid \\
\hline 5 & $\begin{array}{l}\text { Submenu } \\
\text { Antrian } \\
\text { Pasien }\end{array}$ & $\begin{array}{l}\text { Kitk Sub̃mera } \\
\text { Antrian Pasien }\end{array}$ & $\begin{array}{l}\text { Muncul halaman } \\
\text { Farm data tabel } \\
\text { Antrian Pasien }\end{array}$ & $\begin{array}{c}\text { Tampil } \\
\text { Halamean }\end{array}$ & Valid \\
\hline 7 & $\begin{array}{l}\text { Submenu } \\
\text { Antrian } \\
\text { Pasien }\end{array}$ & $\begin{array}{l}\text { KJik Submem } \\
\text { Antrian Pasien }\end{array}$ & $\begin{array}{l}\text { Muncul halaman } \\
\text { Form Input } \\
\text { Diagnosa } \\
\text { Penvakit }\end{array}$ & $\begin{array}{l}\text { Tampil } \\
\text { halaman } \\
\text { Diagnosa } \\
\text { Penvakit }\end{array}$ & Valid \\
\hline 8 & $\begin{array}{c}\text { Subenemu } \\
\text { Antrian } \\
\text { trasien }\end{array}$ & $\begin{array}{l}\text { Strk Jibuens } \\
\text { Antrian Pasien }\end{array}$ & $\begin{array}{l}\text { Muncul halaman } \\
\text { Form Input Resep } \\
\text { Obat }\end{array}$ & $\begin{array}{c}\text { Tampil } \\
\text { tasaman } \\
\text { Resep } \\
\text { Ohaul }\end{array}$ & Valid \\
\hline 9 & $\begin{array}{c}\text { Submemi } \\
\text { Phsies autah } \\
\text { dipeniks }\end{array}$ & 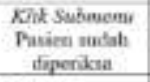 & $\begin{array}{l}\text { Muncul helsman } \\
\text { Dusk tabol wadab } \\
\text { diperiksal }\end{array}$ & $\begin{array}{l}\text { Tampil } \\
\text { talnman }\end{array}$ & Valid \\
\hline 10 & $\begin{array}{l}\text { Suburemi } \\
\text { Laponan } \\
\text { Rekam } \\
\text { Media } \\
\end{array}$ & $\begin{array}{l}\text { Kink Swhinemi } \\
\text { Taparan } \\
\text { Relaan Metis }\end{array}$ & $\begin{array}{l}\text { Muncul halamian } \\
\text { Data nabel pasies }\end{array}$ & $\begin{array}{l}\text { Tampil } \\
\text { halnman }\end{array}$ & Valiat \\
\hline 11. & $\begin{array}{l}\text { Subeneas } \\
\text { Laperan } \\
\text { Relum } \\
\text { Metla }\end{array}$ & $\begin{array}{c}\text { Rlik Submem } \\
\text { Laporan } \\
\text { Rekim Metiis }\end{array}$ & $\begin{array}{l}\text { Muncul halaman } \\
\text { tabel rekam medis }\end{array}$ & $\begin{array}{l}\text { Tampel } \\
\text { haloman } \\
\text { Rehaum } \\
\text { Medis }\end{array}$ & Vatid \\
\hline 12. & $\begin{array}{l}\text { Sulomeiau My } \\
\text { Profile }\end{array}$ & $\begin{array}{l}\text { Sint Subusemi } \\
\text { Afy Prafile }\end{array}$ & $\begin{array}{c}\text { Muncul 1tsiamana } \\
\text { Ago Prafile }\end{array}$ & $\begin{array}{l}\text { Tampi } \\
\text { Ilalaman }\end{array}$ & Vatiat \\
\hline 13. & $\begin{array}{l}\text { Subunemi } \\
\text { Cpdote } \\
\text { Protice }\end{array}$ & $\begin{array}{l}\text { Khik Subuever } \\
\text { Upudate Profilie }\end{array}$ & $\begin{array}{l}\text { Muncut Palaman } \\
\text { Eder Profile }\end{array}$ & $\begin{array}{c}\text { Tampia } \\
\text { Haisman }\end{array}$ & Valid \\
\hline 14. & $\begin{array}{c}\text { Menu Header } \\
\text { Dokter }\end{array}$ & $\begin{array}{l}\text { Klok monus } \\
\text { Heaider Datser }\end{array}$ & $\begin{array}{l}\text { Muncul Halemium } \\
\text { tabel data dokter }\end{array}$ & $\begin{array}{l}\text { Tampe } \\
\text { Haleman }\end{array}$ & Valid \\
\hline is. & $\begin{array}{c}\text { Menu Header } \\
\text { Jadwal } \\
\text { Pralgek }\end{array}$ & 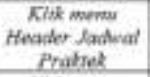 & $\begin{array}{c}\text { Muncul falemen } \\
\text { bbel dats jadwal } \\
\text { praktele }\end{array}$ & $\begin{array}{c}\text { Tampia } \\
\text { Faiseman }\end{array}$ & Valid \\
\hline 16. & $\begin{array}{c}\text { Mesu Header } \\
\text { Pasien }\end{array}$ & $\begin{array}{c}\text { Klds movei } \\
\text { Hender Powiew }\end{array}$ & $\begin{array}{l}\text { Munceal Haleman } \\
\text { tabel tata pasiose }\end{array}$ & $\begin{array}{l}\text { Tampel } \\
\text { Halaman }\end{array}$ & Valid \\
\hline 17. & $\begin{array}{c}\text { Memu Heades } \\
\text { Antrian } \\
\text { Pasien }\end{array}$ & $\begin{array}{c}\text { Kink mowu } \\
\text { Heander } \\
\text { Antrier Plavien }\end{array}$ & $\begin{array}{l}\text { Muncul thlaman } \\
\text { data tabet antrias } \\
\text { pasien }\end{array}$ & $\begin{array}{l}\text { Tampd } \\
\text { Italeman }\end{array}$ & Valid \\
\hline 18. & $\begin{array}{l}\text { Sobubeun } \\
\text { Logoun }\end{array}$ & $\begin{array}{c}\text { Kilk Submem } \\
\text { Logont }\end{array}$ & $\begin{array}{c}\text { Tampd Form } \\
\text { Login }\end{array}$ & $\begin{array}{c}\text { Tampil } \\
\text { Halamum } \\
\end{array}$ & Valid \\
\hline
\end{tabular}

Tabel 3. Hasil Pengujian Kelola Data Pasien

\begin{tabular}{|c|c|c|c|c|c|}
\hline No. & Jenis $\mathrm{Ljj}_{\mathrm{j}}$ & Data $\mathrm{Lj}_{\mathrm{j}}$ & $\begin{array}{l}\text { Hasil yang } \\
\text { Diharapkan }\end{array}$ & $\begin{array}{c}\text { Hasil } \\
\text { Keluaran }\end{array}$ & $\begin{array}{l}\text { Hasil } \\
\tau_{j i}\end{array}$ \\
\hline 1 & $\begin{array}{c}\text { Submenu } \\
\text { Tambah } \\
\text { Data }\end{array}$ & $\begin{array}{c}\text { Klik } \\
\text { Submenu } \\
\text { Tambah }\end{array}$ & $\begin{array}{c}\text { Muacul form } \\
\text { tambah data } \\
\text { dokster }\end{array}$ & $\begin{array}{c}\text { Tampil } \\
\text { form tambah } \\
\text { data pasien }\end{array}$ & Valid \\
\hline 2 & $\begin{array}{l}\text { Button } \\
\text { Simpan }\end{array}$ & $\begin{array}{l}\text { Nomer KTP } \\
\text { tidak diisi }\end{array}$ & $\begin{array}{l}\text { Tampil pesan } \\
\text {-Data harus disisi" }\end{array}$ & $\begin{array}{l}\text { Tampil } \\
\text { pesan }\end{array}$ & Valid \\
\hline 3 & $\begin{array}{l}\text { Button } \\
\text { Simpan }\end{array}$ & $\begin{array}{c}\text { Nama Pasien } \\
\text { tidak diisi }\end{array}$ & $\begin{array}{l}\text { Tampil pesan } \\
\text { "Data harus disisi" }\end{array}$ & $\begin{array}{l}\text { Tampil } \\
\text { pesan }\end{array}$ & Valid \\
\hline 4 & $\begin{array}{l}\text { Butron } \\
\text { Simpan }\end{array}$ & $\begin{array}{l}\text { Status Pasien } \\
\text { tidak diisi }\end{array}$ & $\begin{array}{l}\text { Tampil pesan } \\
\text { 'Data harus disisi" }\end{array}$ & $\begin{array}{l}\text { Tampil } \\
\text { pesan }\end{array}$ & Valid \\
\hline 5 & $\begin{array}{l}\text { Button } \\
\text { Simpan }\end{array}$ & $\begin{array}{l}\text { Upload Foto } \\
\text { KTP } \\
\text { tidak diisi }\end{array}$ & $\begin{array}{l}\text { Tampil pesan } \\
\text {-Data harus dissi" }\end{array}$ & $\begin{array}{l}\text { Tampil } \\
\text { pesan }\end{array}$ & Valid \\
\hline 6 & $\begin{array}{l}\text { Button } \\
\text { Simpan }\end{array}$ & $\begin{array}{l}\text { Upload foto } \\
\text { rujukan } \\
\text { tidak diisi }\end{array}$ & $\begin{array}{l}\text { Tampil pesan } \\
\text {-Data harus dissi" }\end{array}$ & $\begin{array}{l}\text { Tampil } \\
\text { pesan }\end{array}$ & Valid \\
\hline 7 & $\begin{array}{l}\text { Button } \\
\text { Simpan }\end{array}$ & $\begin{array}{l}\text { Nomer bpjs } \\
\text { tidak diisi }\end{array}$ & $\begin{array}{c}\text { Tampil pesan } \\
\text { Data harus dusi" }\end{array}$ & $\begin{array}{l}\text { Tampil } \\
\text { pesan }\end{array}$ & Valid \\
\hline 8 & $\begin{array}{l}\text { Butron } \\
\text { Simpan }\end{array}$ & $\begin{array}{c}\text { Jenis kelamin } \\
\text { tidak diisi }\end{array}$ & $\begin{array}{c}\text { Tampil pesan } \\
\text { "Data harus disis" }\end{array}$ & $\begin{array}{l}\text { Tampil } \\
\text { pesan }\end{array}$ & Valid \\
\hline 9 & $\begin{array}{l}\text { Butron } \\
\text { Simpan }\end{array}$ & $\begin{array}{c}\text { Tempat lahir } \\
\text { tidak diisi }\end{array}$ & $\begin{array}{l}\text { Tampil pesan } \\
\text { "Data harus disi" }\end{array}$ & $\begin{array}{l}\text { Tampil } \\
\text { pesan }\end{array}$ & Valid \\
\hline 10 & $\begin{array}{l}\text { Button } \\
\text { Simpan }\end{array}$ & $\begin{array}{c}\text { Tanggal lahir } \\
\text { tidak diisi }\end{array}$ & $\begin{array}{l}\text { Tampil pesan } \\
\text { "Data harus dusi" }\end{array}$ & $\begin{array}{l}\text { Tampil } \\
\text { pesan }\end{array}$ & Valid \\
\hline 11 & $\begin{array}{l}\text { Button } \\
\text { Simpan }\end{array}$ & $\begin{array}{c}\text { alamat } \\
\text { tidak diisi }\end{array}$ & $\begin{array}{l}\text { Tampil pesan } \\
\text { "Data harus dissi" }\end{array}$ & $\begin{array}{l}\text { Tampil } \\
\text { pesan }\end{array}$ & Valid \\
\hline 11 & $\begin{array}{l}\text { Butront } \\
\text { Simpan }\end{array}$ & $\begin{array}{c}\text { telpon } \\
\text { tidak diisi }\end{array}$ & $\begin{array}{c}\text { Tampil pesan } \\
\text { "Data harus disisi" }\end{array}$ & $\begin{array}{l}\text { Tampil } \\
\text { pesan }\end{array}$ & Valid \\
\hline 11 & $\begin{array}{l}\text { Button } \\
\text { Simpan }\end{array}$ & $\begin{array}{l}\text { username } \\
\text { tidak diisi }\end{array}$ & $\begin{array}{c}\text { Tampil pesan } \\
\text { "Data harus dissi" }\end{array}$ & $\begin{array}{l}\text { Tampil } \\
\text { pesan }\end{array}$ & Valid \\
\hline 11 & $\begin{array}{l}\text { Butron } \\
\text { Simpan }\end{array}$ & $\begin{array}{l}\text { password } \\
\text { tidak diisi }\end{array}$ & $\begin{array}{l}\text { Tampil pesan } \\
\text { 'Data harus disisi" }\end{array}$ & $\begin{array}{l}\text { Tampil } \\
\text { pesan }\end{array}$ & Valid \\
\hline 12 & $\begin{array}{l}\text { Button } \\
\text { Selesai }\end{array}$ & $\begin{array}{l}\text { Klik Button } \\
\text { Selesai }\end{array}$ & $\begin{array}{c}\text { Muncul halaman } \\
\text { tabel } \\
\text { Data Pasien }\end{array}$ & $\begin{array}{l}\text { Tampil } \\
\text { Halaman }\end{array}$ & Valid \\
\hline 13 & $\begin{array}{c}\text { Burton } \\
\text { Eolit }\end{array}$ & $\begin{array}{c}\text { Klik Button } \\
\text { Edit }\end{array}$ & $\begin{array}{l}\text { Tampil form edit } \\
\text { data pasien }\end{array}$ & $\begin{array}{l}\text { Tampil } \\
\text { form }\end{array}$ & Valid \\
\hline 14 & $\begin{array}{l}\text { Button } \\
\text { Delete }\end{array}$ & $\begin{array}{l}\text { Klik Bumton } \\
\text { Delete }\end{array}$ & $\begin{array}{c}\text { Tampil dialog } \\
\text { konfirmasi bapus }\end{array}$ & $\begin{array}{l}\text { Tampil } \\
\text { disilog }\end{array}$ & Valid \\
\hline
\end{tabular}

Tabel 4. Hasil Pengujian Kelola Pendaftaran

\begin{tabular}{|c|c|c|c|c|c|}
\hline No. & Jeais Uji & Data Uji & $\begin{array}{l}\text { Hasil yang } \\
\text { Diharapkina }\end{array}$ & $\begin{array}{c}\text { Hasil } \\
\text { Kelaranan }\end{array}$ & $\begin{array}{l}\text { Hasil } \\
\text { tji }\end{array}$ \\
\hline 1 & $\begin{array}{c}\text { Memu } \\
\text { Pendaftaran }\end{array}$ & $\begin{array}{l}\text { Kitit Memu } \\
\text { Peudaftaran }\end{array}$ & $\begin{array}{c}\text { Muncul } \\
\text { halaminan } \\
\text { Form Data } \\
\text { Pasien } \\
\end{array}$ & $\begin{array}{c}\text { Tampil } \\
\text { Halaman }\end{array}$ & Valid \\
\hline 2 & $\begin{array}{c}\text { Burtom } \\
\text { Poli }\end{array}$ & $\begin{array}{c}\text { Poli } \\
\text { tidak dipilih }\end{array}$ & $\begin{array}{c}\text { Tampil pesan } \\
\text { "Poli harns } \\
\text { dipilin dahulat" }\end{array}$ & $\begin{array}{l}\text { Tampil } \\
\text { pesan }\end{array}$ & Valid \\
\hline 3 & $\begin{array}{c}\text { Buttow } \\
\text { Proses (Cek } \\
\text { Kode Pasien) }\end{array}$ & $\begin{array}{c}\text { Kilk Buitton } \\
\text { Proses }\end{array}$ & $\begin{array}{c}\text { Mnncul } \\
\text { halaninan } \\
\text { Data Pasien }\end{array}$ & $\begin{array}{c}\text { Tampil } \\
\text { Halaman }\end{array}$ & Valid \\
\hline 4 & $\begin{array}{l}\text { Burton } \\
\text { Selesai }\end{array}$ & $\begin{array}{c}\text { Khik Burton } \\
\text { Selesai }\end{array}$ & $\begin{array}{c}\text { Tampil pesan } \\
\text { Success, } \\
\text { Proses } \\
\text { berhasil" }\end{array}$ & $\begin{array}{l}\text { Tampil } \\
\text { Halaman }\end{array}$ & Valid \\
\hline
\end{tabular}

Jessica Felicia Callista, Lena Magdalena, Rifqi Fahrudin 
Tabel 5. Hasil Pengujian Kelola Antrian Pasien

\begin{tabular}{|c|c|c|c|c|c|}
\hline $\mathrm{No}$. & Jenis Uji & Data $\mathrm{UJ}$ & $\begin{array}{l}\text { Hasil yang } \\
\text { Diharapkan }\end{array}$ & $\begin{array}{c}\text { Hasil } \\
\text { Keluaran }\end{array}$ & $\begin{array}{l}\text { Hasil } \\
\text { Uji }\end{array}$ \\
\hline 1 & $\begin{array}{c}\text { Submenu } \\
\text { Antrian Pasien }\end{array}$ & $\begin{array}{l}\text { Klik subMenu } \\
\text { Antrian Pasien }\end{array}$ & $\begin{array}{c}\text { Mrocul } \\
\text { halaman } \\
\text { Data tabel } \\
\text { ancrian pasien }\end{array}$ & $\begin{array}{l}\text { Tampil } \\
\text { Halaman }\end{array}$ & Valid \\
\hline 2 & $\begin{array}{l}\text { Burton } \\
\text { process }\end{array}$ & $\begin{array}{l}\text { Xlik button } \\
\text { process }\end{array}$ & $\begin{array}{c}\text { Miracul } \\
\text { balaman Form } \\
\text { Diagnosa } \\
\text { Penyakit. }\end{array}$ & $\begin{array}{l}\text { Tampil } \\
\text { Halaman }\end{array}$ & Valid \\
\hline 3 & $\begin{array}{l}\text { Butron } \\
\text { Simpan }\end{array}$ & $\begin{array}{l}\text { gejala } \\
\text { tidak dissi }\end{array}$ & $\begin{array}{c}\text { Tampil pesan } \\
\text { "Data harus } \\
\text { dusi" }\end{array}$ & $\begin{array}{l}\text { Tampil } \\
\text { pesan }\end{array}$ & Valid \\
\hline 4 & $\begin{array}{l}\text { Burton } \\
\text { Simpan }\end{array}$ & $\begin{array}{l}\text { diagnosa } \\
\text { tidak disisi }\end{array}$ & $\begin{array}{l}\text { Tampil pesan } \\
\text { "Data harrus } \\
\text { dusi" }\end{array}$ & $\begin{array}{l}\text { Tampil } \\
\text { pesan }\end{array}$ & Valid \\
\hline 5 & $\begin{array}{l}\text { Button } \\
\text { Simpan }\end{array}$ & $\begin{array}{l}\text { findakan } \\
\text { tidak disisi }\end{array}$ & $\begin{array}{l}\text { Tampil pesan } \\
\text { "Data harus } \\
\text { dussi" }\end{array}$ & $\begin{array}{l}\text { Tampil } \\
\text { pesan }\end{array}$ & Valid \\
\hline 6 & $\begin{array}{l}\text { Buston } \\
\text { Simpan }\end{array}$ & $\begin{array}{l}\text { Dirojuk ke rs } \\
\text { tióak disisi }\end{array}$ & $\begin{array}{l}\text { Tampil pesan } \\
\text { "Data haras } \\
\text { divis" }\end{array}$ & $\begin{array}{l}\text { Tampil } \\
\text { pesan }\end{array}$ & Valid \\
\hline 7 & $\begin{array}{l}\text { Button } \\
\text { Selesai }\end{array}$ & $\begin{array}{l}\text { Klik Buttion } \\
\text { Selesai }\end{array}$ & $\begin{array}{c}\text { Tampil pesan } \\
\text { "Success, } \\
\text { Proses } \\
\text { berhasil" }\end{array}$ & $\begin{array}{c}\text { Tampil } \\
\text { Halaman } \\
\text { Fom Input } \\
\text { Resep obat }\end{array}$ & Valid \\
\hline 8 & $\begin{array}{l}\text { Button } \\
\text { Simpen }\end{array}$ & $\begin{array}{l}\text { Nama obat } \\
\text { tidak diisi }\end{array}$ & $\begin{array}{c}\text { Tampil pesan } \\
\text { "Data harus } \\
\text { disis" }\end{array}$ & $\begin{array}{l}\text { Tampil } \\
\text { pesan }\end{array}$ & Valid \\
\hline 9 & $\begin{array}{l}\text { Batton } \\
\text { Simpan }\end{array}$ & $\begin{array}{l}\text { quantity } \\
\text { tidak disi }\end{array}$ & $\begin{array}{l}\text { Tampil pesan } \\
\text { "Data harus } \\
\text { disis" }\end{array}$ & $\begin{array}{l}\text { Tampil } \\
\text { pesan }\end{array}$ & Valid \\
\hline 10 & $\begin{array}{l}\text { Buston } \\
\text { Selesai }\end{array}$ & $\begin{array}{l}\text { Klik Button } \\
\text { Selesai }\end{array}$ & $\begin{array}{c}\text { Tampil pesan } \\
\text { "Success, } \\
\text { Proses } \\
\text { berhasil" }\end{array}$ & $\begin{array}{c}\text { Tampil } \\
\text { Halaman } \\
\text { Data tabel } \\
\text { pasien } \\
\text { sudah } \\
\text { diperiksa }\end{array}$ & Valid \\
\hline
\end{tabular}

\section{Medis}

Tabel 6. Hasil Pengujian Laporan Rekam

\begin{tabular}{|c|c|c|c|c|c|}
\hline No. & Jenis Uji & Data Uji & $\begin{array}{l}\text { Hasil yang } \\
\text { Dilarazlan }\end{array}$ & Hasil Keluaran & $\begin{array}{l}\text { Hasi } \\
\text { Uji }\end{array}$ \\
\hline 1 & $\begin{array}{l}\text { Metil } \\
\text { Laporan } \\
\text { rekam } \\
\text { madis }\end{array}$ & $\begin{array}{c}\text { Klik } \\
\text { merw } \\
\text { laporan } \\
\text { rekam } \\
\text { medis }\end{array}$ & $\begin{array}{c}\text { Muncil } \\
\text { balaman } \\
\text { Data tabel } \\
\text { pasien }\end{array}$ & Tampil Halaman & Valid \\
\hline 2 & $\begin{array}{l}\text { Baitton } \\
\text { pilih }\end{array}$ & $\begin{array}{l}\text { Klik } \\
\text { buttan } \\
\text { pilîh }\end{array}$ & $\begin{array}{c}\text { Nuncul } \\
\text { halaman data } \\
\text { tabel rekam } \\
\text { medis }\end{array}$ & $\begin{array}{l}\text { Tampil Halaman tabel } \\
\text { rekrm medis }\end{array}$ & Valid \\
\hline 3 & $\begin{array}{c}\text { Burtan } \\
\text { donziood } \\
\text { padf }\end{array}$ & $\begin{array}{c}\text { Kilk } \\
\text { button } \\
\text { dininload }\end{array}$ & $\begin{array}{l}\text { Mroxul Cetak } \\
\text { laporan } \\
\text { relam medis }\end{array}$ & $\begin{array}{c}\text { Meryimpan } \\
\text { laporan_rekam_medis.pdf }\end{array}$ & Valid \\
\hline
\end{tabular}

\section{III.6 Evaluasi Sistem}

Pengguna berdasarkan hasil pengujian maka dapat disimpulkan bahwa sistem dapat diterima dan digunakan oleh pengguna.

\section{III.7 Menggunakan system}

Software yang telah diuji dan diterima pengguna siap untuk di implementasikan.

\section{KESIMPULAN DAN SARAN}

Berdasarkan hasil pengujian, maka aplikasi telah dapat dijalankan dengan baik dan sesuai dengan kebutuhan. Dari hasil pengujian aplikasi tersebut, menghasilkan suatu sistem yang berbasis website yang mempermudah dalam proses pendaftaran pasien, pengelolaan data petugas, pendataan tindakan medis, penyerahan obat sehingga dapat terjadi perubahan dari proses manual menjadi terkomputerisasi..

Saran selanjutnya adalah menambahkan fitur fitur dalam aplikasi tersebut seperti dapat menambahkan kelola sistem pelayanan lainnya serta menambahkan pengelolaan clustering data penyakit.

\section{REFERENSI}

Fauzan, F., \& Effiyaldi, E. (2018). Analisis Perancangan Sistem Informasi Perpustakaan Berbasis Web (Studi Kasus: Sma At-Taufiq Kota Jambi). Jurnal Manajemen Sistem Informasi, 3(2), 1041-1052.

Rahman, T., Hakim, L., \& Sari, O. M. (2020). SISTEM INFORMASI REKAM MEDIS PADA DINAS KESEHATAN KABUPATEN MUSIRAWAS BERBASIS WEB MOBILE. JUTIM (Jurnal Teknik Informatika Musirawas), 5(2), 141-156.

Sintawati, I. D., \& Widiarina, W. (2020). Penerapan Metode Prototype Untuk Sistem Informasi Pengadaan Barang Berbasis Web. Jurnal Akrab Juara, 5(4), 206-215.

Ulfa, H. M. (2018). Analisis Unsur Manajemen dalam Pengolahan Rekam Medis di Rumah Sakit TNI AU Lanud Roesmin Nurjadin. Kesmars, 1(1), 2025.

Ida, R. (2018). Etnografi virtual sebagai teknik pengumpulan data dan metode. 